MARGRÉT JóNSDÓTTIR

\title{
Borges y la literatura islandesa medieval ${ }^{1}$
}

Tarde o temprano los historiadores de la novela habrán de reconocer la importancia de la saga. Alguna vez se escribirá la historia de la metáfora, y se comprobará que ciertos excesos del siglo XVII y del siglo XX tuvieron anticipación en Islandia. ${ }^{2}$

\section{Introducción}

El escritor argentino Jorge Luis Borges estuvo tres veces en Islandia: en 1971, 1976 y 1978. Desde joven se había interesado por una de las sagas escritas en los siglos XIII y XIV ya que en la extensa biblioteca de su padre encontró la traducción al inglés de Völsungasaga hecha por Eiríkur Magnússon y William Morris en 1870. De esta lectura surgió el encendido interés por la literatura medieval islandesa, la que expresará más tarde en su poema "A Islandia":

Islandia, te he soñado largamente Desde aquella mañana en que mi padre

Le dio al niño que he sido y que no ha muerto Una versiớn de la Völsunga Saga

${ }^{1}$ Quisiera dar las gracias a mis amigos Viola Miglio, quien corrigí todo pensamiento oscuro, y a José Luis Martín García-Arista, quien revisó mi español.

${ }^{2}$ Jorge Luis Borges, Antiguas literaturas germánicas, Fondo de Cultura Económica, México, 1951, p. 8. 
El encuentro con Völsungasaga tuvo lugar antes de su viaje a Ginebra en 1914, es decir, antes de cumplir quince años; fue entonces su primer contacto con la cultura islandesa. Su gusto por las sagas aumentó con el tiempo y cuando fue a Islandia en su "viaje de peregrino", como dijo, ya podía entender la lengua con la ayuda de un diccionario. ${ }^{4}$

Fruto de esta afición son tres libros sobre la cultura islandesa medieval: Las kenningar, publicado en 1933, Antiguas literaturas germánicas, publicado en 1951, y Literaturas germánicas medievales, publicado en 1966.5 Por último, en colaboración con María Kodama, tradujo al español en 1984 Gylfaginning o La alucinación de Gylfi, la cual es una parte de la Edda de Snorri Sturluson. ${ }^{6}$ Puede observarse, pues, un intervalo entre la primera y la última de más de medio siglo, lo cual muestra que su pasión por lo islandés no era una mera curiosidad efímera, sino algo más profundo que se tejía en su biografía y en su obra, y que su interés por la literatura de ese país estuvo presente en gran parte de su vida.

Lo que caracteriza la crítica literaria sobre Borges con respecto a estos temas es que los críticos se han dedicado a obte403

3 J. L. Borges, Obra poética 1923-1976. Emecé, Buenos Aires, 1977, p.

${ }^{4}$ Matthías Johannesen, Samtöl II. "Biðð getiơ andað̃ hérna fyrir stjórnvöldum" ("Aqú las autoridades permiten que respirćis en paz". (Entrevista)). Reykjavik, 1978, p. 219. Matthías Johannesen, en una carta que me escribió en diciembre de 1993, dijo que el interés idiomático de Borges era más de tipo etimológico que hacia la lengua moderna.

${ }_{5}$ Toda la bibliografía que he consultado dice que el libro fue editado en 1966 pero el ejemplar que consulté de la biblioteca Firestone en Princeton tiene la fecha 1965.

${ }^{6}$ Snorri Sturluson, La alucinación de Gylfi, traducción de J. L. Borges y M. Kodama, Alianza, Madrid, 1984. En este mismo año apareció otra traducción del texto en la misma editorial y en 1983 había salido otra en Editora Nacional. Las tres traducciones del mismo libro tenían títulos distintos, pero esta confusión es al mismo tiempo testigo de lo poco que se sabe de la literatura islandesa medieval en los países de lengua española. 
ner información sobre la propia escritura de los mencionados textos pero no entran en el tema tratado, que es la literatura islandesa; el interés se centra en deducir la teoría literaria de Borges, lo cual quizás sea lo más interesante; pero lo otro queda por hacer. Hay un desinterés general por estas obras o, como dice Bernárdez:

Ese desinterés parece auténtico, pues ni el artículo ni el libro [se refiere a Las kenningar] sirvieron para paliar el radical desconocimiento de las antiguas literaturas nórdicas de que hacían gala los historiadores literarios españoles (y creo que latinoamericanos), signo probable de que ninguno de ellos se había preocupado por leer las páginas de Borges. ${ }^{7}$

Las obras de Borges aquí discutidas no se han considerado como obras académicas sino como literatura, lo cual es comprensible debido a su carácter de mezcla entre lo erudito y la fascinación personal por los temas tratados.

En este trabajo me limito a lo que Borges escribió sobre Islandia en particular, y omito otras literaturas germánicas. ${ }^{8}$ Tres aspectos me atraen principalmente:

1. ¿Cuál es el valor informativo de los libros? Sorprendentemente ningún académico islandés ha evaluado estos escritos de Borges. No obstante, la parte de las Antiguas literaturas germánicas que trata de lo escandinavo, sí ha sido traducida al noruego. ${ }^{9}$ Por lo tanto se trata de un texto conocido pero no

7 Enrique Bernárdez, "Borges y el mundo escandinavo", Cuadernos Hispanoamericanos 505-507 (julio-septiembre 1992), p. 361. Aparte de una reseña corta que salió en Noruega en 1969 a la que aludiremos más adelante, Bernárdez es el primero que se acerca a estos textos de Borges con otra perspectiva, evaluando brevemente lo que ha escrito sobre las literaturas germánicas.

${ }^{8}$ No hay espacio para tratar su poesía inspirada en la literatura islandesa medieval e Islandia hoy en día. En 1966 publicó por ejemplo Seis poemas escandinavos en una edición privada con solamente 84 ejemplares. Otros poemas son, por ejemplo, "Snorri Sturluson" y "A Islandia" en El oro de los tigres; "Einar Tambarskelver" y "En Islandia el alba" en La moneda de hierro, y "Midgarthormr" en Atlas.

9 J. L. Borges, Den norröne litteratur, trad. por Hans Erich Lampl y Niels Magnus Bugge, Oslo, 1969. 
trabajado, exceptuando una pequeña reseña de esta edición noruega.

2. ¿Qué fue lo que le atrajo y le interesó al escritor al leer los textos islandeses? Sus comentarios revelan su preferencia y su gusto. Estos comentarios estilísticos nos guían en busca de similaridades o influencias en la obra del autor. No sabemos si se trata de afinidades de estilo o de una verdadera influencia de la cultura islandesa.

3. Para esbozar el específico interés de Borges en la literatura islandesa, intentaré sacar a la superficie un subtexto islandés en dos relatos del autor. En general, cuando se habla de términos como fuente, subtexto, intertexto y reescritura hay mucha confusión. Kiril F. Taranovsky, quien introdujo el término 'subtexto', lo define como "una referencia o alusión dentro de una obra determinada a un texto literario anterior, el conocimiento del cual es importante para el significado de la obra que contiene la alusión". "0 Así lo interpretaremos en este escrito. Hasta ahora, la crítica no ha tomado en cuenta la existencia de este subtexto islandés, pero a mi parecer, encontrarlo y ver las alusiones y relaciones, puede dar a conocer otra dimensión en la obra del autor, al mismo tiemp̣o que permite aclararla. En los cuentos que voy a tratar, es importante conocer las características de las sagas y de los poemas escáldicos, además de entender bien las alusiones a este mundo. Además del subtexto, hay una temática escandinava explícita que no hace más que mostrar su interés por esta parte del mundo y su universalidad. ${ }^{11}$

:0 Adrián García Montoro, "Subtexto en 'El inmortal' y 'Deutsches Requiem'", Hispamérica 21 (1978), p. 4.

"11 Ver el artículo de Joseph Tyler, "Borges y las literaturas germánicas en El libro de arena", Hispanic Journal 2 (1980), pp. 79-85. Allf subraya la influencia germánica en varios cuentos de El libro de arena. Se mantiene, no obstante, en el nivel de temática y deja afuera el elemento más importante, el estilo. Dice: "El Libro de arena parece ser un ejemplar donde se concentran todos estos elementos germánicos medievales", p. 83. No define cuáles son "todos estos elementos" y sigue: "Borges, como bien se sabe, hace literatura de la Literatura. Los relatos de El libro de arena, como algunos de 
El subtexto es esencial e implícito en su obra. Para demostrarlo quisiera trabajar los siguientes cuentos: "Tlön, Uqbar, Orbis Tertius" y "La intrusa". Mi meta última es poder averiguar la presencia de un subtexto islandés en la obra de Borges o si, en su defecto, hay simplemente una cierta similitud de estilo entre las sagas y el suyo. ${ }^{12}$

\section{Las kenningar (1933)}

En este librillo de apenas treinta páginas, Borges reflexiona sobre el sistema metafórico islandés, las denominadas kenningar, que aparecen en los versos escáldicos muy a menudo intercalados en las sagas. En islandés los versos escáldicos se llaman dróttkvaeði que significa versos de la corte. Éstos se desarrollaron, primero en Noruega y luego en Islandia, durante los siglos IX y X. Gran parte de los versos escáldicos son de carácter laudatorio y hablan de reyes, condes y otros hombres principales. Aparte de esto, la temática era muy variada. Una característica esencial de los versos escáldicos es que no eran anónimos, todos tenían autor, por lo cual eran excepcionales en esta cultura, caracterizada por ser sumamente oral.

Como fuente principal para su libro, Borges se basa en Snorra Edda, de Snorri Sturluson (1179-1241), el escritor y político más importante en la Islandia de su tiempo. Se ha supuesto que escribió varios libros pero solamente éste es. suyo con toda seguridad, aunque pocos duden que sea el autor de Heimskringla. Escrita alrededor de 1230, Snorra Edda explica la mitolo-

Ios poemas borgianos que provienen de la misma fuente, son versiones de las historias de las literaturas germánicas medievales", p. 84. Hemos entrado en el tema de la reescritura elaborado por Michel Lafon, pero no me parece que podamos hablar de versiones de las historias de las literaturas germánicas. Las teorias de Tyler carecen de esenciales referencias precisas.

${ }^{12}$ Sigrún Á. Eiríksdóttir es la primera persona que ha tocado el tema del subtexto islandés en la obra de Borges. "Borges' Icelandic Subtext: The Saga Model", Neophilologus 71 (1987), pp. 381-87. 
gía nórdica, y ante todo la retórica y poética en los versos escáldicos. Sirvió de ars poetica a los poetas jóvenes.

En cuanto a las kenningar, se trata de un procedimiento muy complicado que a medida que pasó el tiempo se intensificó y subió de grado hasta terminar en un nivel casi indescifrable. En su presentación más simple, una kenning no es más que una metáfora o una perífrasis, y está dividida en dos partículas, es decir, compuesta de dos sustantivos, uno de los cuales va en nominativo (la palabra de base) y el otro va generalmente en genitivo, formando una palabra compuesta. Ejemplo de esto sería la kenning fuglheimur o 'morada del pájaro', que significa 'el aire'.13 'La morada' es la palabra de base y 'del pájaro' es la palabra que define la primera, dándole un significado determinado. Ambas partículas, a su vez, se podían dividir para crear otras nuevas en un grado superior. Por ejemplo: una kenning conocida para representar el cielo era 'yelmo del aire'; si se intensifica, gracias a su combinación con la anterior, que significa, como se vio, 'aire', el resultado es: 'yelmo de la morada del pájaro'. Como se ve, descifrar las kenningar se vuelve paulatinamente más arduo a medida que se sube de nivel. Asimismo, su comprensión requería muy a menudo conocimientos de mitología nórdica y muchas de las kenningar ininteligibles hoy en día se basan en leyendas que se consideran perdidas. ${ }^{14}$

Borges no es insensible a la originalidad de las kenningar cuando dice: "Retenerlas y aplicarlas sin repetirse, era el ansioso ideal de esos primitivos hombres de letras". ${ }^{15}$ ¿Se refiere al siglo $\mathrm{X}$ ? No lo sabemos, pero es necesario tener en cuenta que así era al comienzo, antes de que las kenningar se convirtieran en tropos. Esto último es muy visible en los escritos de Snorri, donde el autor subraya el sistema de las kenningar no como un

:3 Habla de casa de los pájaros, Las kenningar. Buenos Aires, 1933, p. 13. Es una traducción inexacta. 'Heimur' significa 'mundo' en islandés, pero como palabra compuesta significa 'domicilio' o 'morada'.

${ }_{14}^{14}$ Régis Boyer, La poésie scaldique, Turnhout-Belgium, 1992, pp. 22-24.

is J. L. Borges, Las kenningar, p. 8 
camino original sino como algo ya hecho. ${ }^{16}$ Hay aquí un cierto prescriptivismo porque Snorri, como Borges, hace una especie de diccionario. ${ }^{17}$ El primero no habla de las posibilidades de las kenningar, sino de cómo deben componerse: "Hvernig skal kenna skip? Svo að kalla hest eða dýr eða skíð sækonunga eða sævar eða skipreiða eða veðurs”. (¿Cómo se hace una kenning para barco? Llamándolo el caballo, el animal o la tabla de los reyes del mar o del mar o del mástil o del tiempo atmosférico). ${ }^{18}$ Como las posibilidades no son infinitas, a continuación, Snorri cita doce poemas escáldicos con kenningar de esta índole para fundamentar lo que dice, dando todas las posibilidades conocidas. Con ello, rescata la tradición literaria e insiste en que debe ser respetada. Abundan frases como "es correcto", "es debido", "es necesario", "no es necesario". Es decir, tiene que ser usado lo que existe en la tradición poética; la tradición se institucionaliza por medio de "esta especie de diccionario.

Debe destacarse que la intención de Borges es muy diferente a la de Snorri Sturluson, quien componía una obra preceptiva para poetas y no para los curiosos letrados de un país lejano. La relación de Borges con las kenningar es principalmente personal y el autor se entrega totalmente al texto. A veces está como fascinado y en otros momentos expresa aversión, como apuntan Karen Lynn y Nicolas Shumway:

Por una parte, Borges disminuye su importancia, llamándolas "frías aberraciones", "laboriosas e inútiles", "desfallecidas flo-

${ }^{16}$ Claro, puesto que Snorri escribe alrededor de 1230 , o sea, tres siglos después del auge de los poemas escáldicos. Uso el nombre de pila de Snorri porque en Islandia nunca usamos el apellido sino cuando va junto con el nombre. El apellido por sí solo no tiene sentido para un islandés.

17 En un ensayo "Otra vez la metáfora", en El idioma de los argentinos, de 1928, Borges mantiene que una computación o catálogo de metáforas serviría de poco. Hay que preguntarse hasta qué punto el libro Las kenningar no es, él mismo, una computación o catálogo de metáforas.

I8 Snorri Sturluson, Snorra Edda, Reykjavík, 1984, p. 166. Me refiero al tiempo en el sentido de weather. 
res retóricas" [...] Por otra parte, y paradojicamente, Borges muestra una genuina fascinación con las kenningar. ${ }^{19}$

También señalan cómo este autor mantenía su interés por las kenningar a pesar de "los cambios radicales [...] en las teorías de Borges sobre la metáfora y su función en la poesía" a lo largo de los años. Según ellos:

las kenningar sirven de puente entre el Borges joven y el Borges maduro, reclamando su atención y apreciación desde posiciones conflictivas. De una manera sorprendente, las kenningar, a pesar de lo inflexibles y normativas que son, satisfacen en sus diferentes aspectos las dos nociones borgianas de la metáfora. ${ }^{20}$

Ya que el libro sobre las kenningar fue escrito en la aurora de su carrera literaria, poco después de que rechazó el ultraísmo, parece que hay una constante tensión entre el viejo ultraísta y el Borges de un estilo más escueto y sencillo. Vemos, por lo tanto, una tensión entre atracción y crítica. Es como si las kenningar pertenecieran más a su gusto pasado. Dice: "El ultraísta muerto cuyo fantasma sigue siempre habitándome, goza con estos juegos". 21

Con su libro, Borges da un aspecto totalmente nuevo a este sistema metafórico islandés. Lo resucita y le da un valor nuevo

${ }^{19}$ Karen Lynn y Nicolas Shumway, "Borges y las Kenningar", Texto crítico 2810 (1984), p. 124.

${ }^{20}$ Ibid., p. 127 y 129. Las dos nociones borgianas de las cuales habla son éstas: "El Borges joven buscaba que sus metáforas fueran nuevas y chocantes, y que constituyeran la esencia misma del poema". Toda la poesía era reducible a metáforas porque otros recursos poéticos se habían extenuado. Borges menciona nueve tipos de metáforas y recomienda a los poetas que busquen "la fórmula de la metáfora exitosa en las obras de los grandes artistas, para así derivar nuevas metáforas reunicndo elementos diferentes en las mismas fórmulas", pp. 127-28. Es decir, les recomienda que hagan lo mismo que Snorri Sturluson hizo en el siglo XiI. La segunda etapa se caracteriza por el criterio de Borges que mantiene que "el poeta no debe buscar metáforas "nuevas' en el sentido que una vez propuso" y apunta además que la metáfora no es necesariamente el componente principal de un poema.

${ }^{21} \mathrm{~J}$. L. Borges, Las kenningar, p. 25. 
bajo el prisma original del extranjero. Claro que es un ensayo corto, pero lo esencial es la selección de kenningar. En la mente del islandés, las kenningar tienen que ver principalmente con la mitología nórdica. Al contrario, Borges solamente se interesa por lo universal de las kenningar y deja afuera lo típico islandés, es decir, la mitología nórdica y las complicadas leyendas alrededor. Saca a la luz del público hispanoparlante el aspecto más claro, más fácil de comprender, pero al mismo tiempo el más desatendido por los islandeses. Dice:

Omito las de segundo grado [...] y las de razón mitológica [...] Omito las ocasionales también [...] De las de potencia más alta, de las que opera la fusión arbitraria de los enigmas, indicaré una.sola: los aborrecedores de' la nieve del puesto del halcón. $\mathrm{El}$ puesto del halcón es la mano; la nieve de la mano es la plata; los aborrecedores de la plata son los varones que la alejan de sí, los reyes dadivosos. ${ }^{22}$

Es obvio el aire de gusto personal y hasta caprichoso que domina el tratamiento de las kenningar. Lo que le interesa es compartir con el lector lo que a él mismo le ha interesado. Es como un navegante que cuenta a sus compatriotas lo que ha visto en la tierra lejana y construye un puente cultural entre estas dos civilizaciones que no se conocen. Lo universal es lo que sobre todo le llama la atención y pienso que tal vez ésta sería la manera de presentar las kenningar al público moderno islandés no experto en la mitología. Borges señala la esencia y la gracia del sistema y lo hace áccesible para todo el mundo como juego o desafío a la inteligencia. ${ }^{23}$ Hasta ahora, la crítica

${ }^{22}$ Ibid., p. 18.

${ }^{23}$ Lamentablemente no se puede decir lo mismo de los académicos islandeses que han escrito acerca del asunto. El ejemplo más claro sería el diccionario islandés de retórica y poética, Hugtök og heiti i bókmenntafraði, pp. 144-45. Los ejemplos allí tomados no forman parte del vocabulario del islandés común. Son palabras del islandés medieval que ya necesitan traducción hoy en día. Hay una tendencia elitista como para indicar que esto no lo entiende cualquiera y no se introduce este sistema como si fueran perífrasis graciosas sino algo muy, muy complicado, no accesible para la gente ordinaria. 
literaria escandinava no ha señalado este punto gracioso de las kenningar. Las kenningar es, en consecuencia, más bien una introducción popular y simplificada al sistema metafórico islandés.

La presencia de Borges es muy fuerte en el texto de Las kenningar y su valoración sumamente subjetiva, como demuestra el siguiente párrafo:

Lo que [las kenningar] procuran trasmitir es indiferente, lo que sugieren nulo. No invitan a soñar, no provocan imágenes o pasiones; no son un punto de partida, son términos [...] El agrado [...] está en su variedad, en el heterogéneo contacto de sus palabras. Es posible que así lo comprendieran los inventores y que su carácter de símbolos fuera un mero soborno a la inteligen$\mathrm{cia}^{24}$

Este "mero soborno a la inteligencia" sería un juego de palabras antes que nada, e insiste en la preferencia de la inteligencia a la hora de descifrarlas. Importa más que la sensibilidad poética.

Borges compara las kenningar con procedimientos literarios de otras literaturas, por ejemplo con la de Gracián (16011658):

Baltasar Gracián y Morales, de la Sociedad de Jesús, tiene en su contra unas laboriosas perífrasis, de mecanismo parecido o idéntico al de las kenningar [...] En vez de proponerlas directamente las fue justificando y coordinando con recelo culpable [...] El mensaje de Egill Skallagrímsson es un problema, o siquiera una adivinanza; el del inverosímil español, una confusión. ${ }^{25}$

Esta comparación que hace Borges no es justa, pues está en una de sus fases de antiespañolismo y de allí lo severo del juicio contra Gracián, pues lo saca de contexto y le hace una críti-

24 J. L. Borges, Las kenningar, p. 9.

25 Ibid., pp. 10-11. 
ca comparativa, como si la intención del poeta español hubiera. sido escribir kenningar. No obstante, sería un trabajo interesante comparar el uso de metáforas en el Siglo de Oro español y la Islandia del medioevo.

Para poder trazar las kenningar en el texto de Borges, es necesario conocerlas. Veamos por ejemplo el tratamiento que hace Alazraki de las kenningar en el libro de La prosa narrativa de Borges, quien obviamente no las ha estudiado debidamente y por ello las trata con mucha imprecisión:

En "La viuda Ching, pirata", el subcapítulo 'El dragón y la zorra' alude a "bandadas de dragones livianos que surgían cada atardecer de las naves de la escuadra imperial y se posaban con delicadeza en el agua y en las cubiertas enemigas". (p. 49) Nada se nos dice de esos "livianos dragones" fuera de que, cuando aumentaron; la Viuda se rindió; pero en el catálogo de kenningar, compilado por Borges en su ensayo de 1932, el dragón es la kenning o metáfora para la espada y la lanza. En el mismo texto se alude a la sangre como 'agua rojiza', variante de la kenning, 'agua de la espada' para nombrar la sangre. Hacia el final del mismo relato, derrotada Ia Viuda, el texto concluye: "Los barcos recuperaron la paz. Los cuatro mares y los ríos innumerables fueron seguros y felices caminos". (p. 50), donde se alude al mar evocando dos conocidas kennings que describen el mar como 'camino de las velas' y 'camino de las ballenas'. ${ }^{26}$

Sentí la necesidad citar en extenso a Alazraki para mostrar lo absurdas que son sus afirmaciones. Borges, en su ensayo de 1933 (y no 1932), no dice que "el dragón es la kenning o metáfora para la espada y la lanza". Dice: "el dragón es la vieja amenaza del anochecer". ${ }^{27} \mathrm{El}$ dragón no es la kenning, ésta es "la vieja amenaza del anochecer". Menciona ocho kenningar para la espada, pero ninguna de ellas incluye la palabra dragón. ${ }^{28}$ Parece que Alazraki no se ha dado cuenta de que una

${ }^{26}$ Jaime Alazraki, La prosa narrativa de Borges, Gredos, Madrid, 1983, pp. 425-26.

${ }^{27}$ J. L. Borges, Las kenningar, p. 20.

${ }^{28}$ Ibid., pág. 15. 
kenning está compuesta de dos nombres. 'Agua rojiza' tampoco es variante de la kenning 'agua de la espada', sino es simplemente un nombre acompañado de un adjetivo. Es también obvio que hablar de los mares y los ríos como caminos no es otra cosa que el uso de un lenguaje figurado, y no evoca con ello las kenningar islandesas para el mar. Parece que no entendió la esencia de las kenningar, de ahí las imprecisiones.

Las kenningar en la obra de Borges

A continuación veamos cómo Borges usa este equipamiento cultural a la hora de escribir su obra. En el poema "Fragmento" alude a ellas y dice:

Una espada para la mano

Que regirá la hermosa batalla, el tejido de hombres,

Una espada para la mano

Que enrojecerá los dientes del lobo

$\mathrm{Y}$ el despiadado pico del cuervo,

Una espada para la mano

Que prodigará el oro rojo. ${ }^{2 y}$

Ocho años después de la publicación de Las kenningar, publicó el cuento "Tlön, Uqbar, Orbis Tertius". Allí podemos trazar claramente un subtexto islandés, ${ }^{30}$ pues a lo largo del cuento hay constantes referencias a una realidad escandinava: cuan-

${ }^{29}$ Jorge Luis Borges, "Fragmento", Obra poética 1923-1976. Emecé, Buenos Aires, 1977, pp. 222-23.

${ }^{30}$ La posdata de 1947 es ficticia y el cuento fue publicado por primera vez con esta fecha en Sur, en mayo de 1940. Arturo Echevarría Ferrari, en su artículo "'Tlön, Uqbar, Orbis Tertius': creación de un lenguaje y crítica del lenguaje", en Revista Iberoamericana 100-101 (1977), pp. 399-413, no menciona ninguna relación con las kenningar aunque el contenido trate del idioma creado. Fue el profesor James E. Irby quien me llamó la atención sobre el subtexto islandés en el cuento. Mary H. Lusky, en "Jorge Luis Borges y su lucha con el lenguaje", en Cuadernos Americanos (190) 1973, p. 221, menciona de paso la similitud entre las kenningar y el idioma de Tlön: 
do Borges busca el nombre Uqbar en la enciclopedia, sale el nombre de la ciudad sueca de Upsala. Un noruego sin nombre le había encargado al inglés Herbert Ashe la transcripción de algunas tablas duodecimales a sexagesimales. ${ }^{31}$ En la posdata tropezamos con un tal Gunnar Erfjord, quien obviamente es noruego. Probablemente es el mismo hombre que le encargó a Ashe la transcripción del sistema numérico.

La enciclopedia que alguien había mandado a Ashe, quien "padeció de irrealidad", ${ }^{32}$ era el volumen XI y abarcaba de 'Hlaer' hasta 'Jangr'. Ambas palabras están obviamente de acuerdo con las normas de-la lengua islandesa. 'Hlær' es la tercera persona singular, presente, del verbo 'reírse', que durante el medioevo también significaba alegrarse. 'Jangr' no existe; pero la palabra concuerda con el sistema lingüístico medieval islandés. ${ }^{33} \mathrm{Su}$ terminación está de lacuerdo con el nominativo de los nombres masculinos. La palabra 'Jangr' es la que da el aire medieval, porque alrededor del año 1500 se añadió la vocal u entre las dos consonantes finales de la palabra, y pasó a ser 'Jangur'. Es ésta la primera indicación de que el contenido de la historia de "Uqbar, Tlön y Orbis Tertius" es de índole islandesa. Por lo tanto no nos sorprende la descripción de la Ursprache de Tlön que es una recreación de las kenningar. Dice: "No hay sustantivos en la conjetural Ursprache de Tlön, de la que proceden los idiomas 'actuales' y los dialectos". ${ }^{34}$ En efecto, las kenningar están compuestas de sustantivos y forman un sistema metafórico. Borges retuerce este sistema creando otros; primero de verbos:

"Como las 'kennings' escandinavas, los sustantivos que construyen los tlönistas del norte tienen gran valor descriptivo". Pero no desarrolla la idea.

3: J. L. Borges, Ficciones, Emecé, Buenos Aires, 1989, pp. 14 y 17.

${ }^{32}$ Ibid. p. 17.

${ }^{33}$ Busqué sin éxito la palabra 'jangr' en el diccionario medieval islandés de Sveinbjöm Egilsson, Lexicon Poeticum, segunda edición, Copenhague, 1966, y también en un diccionario de anglosajón, J. Bosworth, Anglo-Saxon Dictionary, Londres, 1838.

${ }^{34}$ J. L. Borges, Ficciones, p. 20. 
Por ejemplo: no hay palabra que corresponda a la palabra luna, pero hay un verbo que sería en español lunecer o lunar. Surgió la luna sobre el río se dice hlör u fang axaxaxas mlö o sea en su orden: hacia arriba (upward) detrás duradero-fluir luneció. ${ }^{35}$

De nuevo vemos que la creatividad y la fantasía del autor forma parte del sistema lingüístico islandés medieval, el cual es la verdadera Ursprache escandinava. Ninguna de las palabras es verdadera, excepto 'fang' que significa 'regazo'. Se trata de una lengua metafórica y compleja, y recuerda lo que el autor había dicho sobre las kenningar, cuando habla de éstas como un juego de la inteligencia. Hace lo mismo aquí, pues concibe una lengua jugando con palabras y con su propia inteligencia, creando metáforas. Esta Ursprache era la del hemisferio sur de Tlön pero, al describir el idioma hablado en el norte lo reconocemos como otra versión de las kenningar, pero esta vez a base de adjetivos: "No se dice luna: se dice aéreo-claro sobre oscuro-redondo o anaranjado-tenue-del cielo o cualquier otra agregación". Estos términos son kenningar por excelencia pero compuestas de adjetivos en vez de sustantivos. Más adelante añade, complicando aún más el sistema: "Hay objetos compuestos de dos términos, uno de carácter visual y otro auditivo: el color del naciente y el remoto grito de un pájaro". ¿Es que los objetos allí son metáforas? El autor complica el sistema de las kenningar, lo invierte y juega con las posibilidades del lenguaje. Habla de objetos y no de kenningar 'de segundo grado' pero remata la descripción con una frase que podría ser una descripción de los poemas escáldicos si trocamos 'palabra' u 'objeto' por kenning. Dice que hay objetos compuestos de una multiplicidad de términos:

Los hay de muchos: el sol y el agua contra el pecho del nadador, el vago rosa trémulo que se ve con los ojos cerrados, la

35 Ibid. pág. 21. Abunda la vocal «ö» que es una vocal diferente a «o» y a « $\sigma »$ en islandés. 
sensación de quien se deja llevar por un río y también por el sueño. Esos objetos de segundo grado pueden combinarse con otros; el proceso, mediante ciertas abreviaturas, es prácticamente infinito. Hay poemas famosos compuestos por una sola enorme palabra. ${ }^{36}$

La descripción es como un poema y, cuando se refiere al segundo grado, no cabe duda de que fácilmente se pueda sustituir 'objetos' y 'palabras' por kenning. La gradación de las kenningar se refleja aún mejor cuando vemos que en Tlön ocurre que los objetos perdidos se duplican. Éstos se llaman hrönir. ${ }^{37}$ Como ya sabemos, hrön significa la copia de un objeto original pero perdido. Sorprendentemente hay una gradación de las hrönir y recordamos que las kenningar pueden del mismo modo subir en grados hasta llegar al séptimo. En este grado es muy difícil descifrarlos:

Hecho curioso: los hrönir de segundo y de tercer grado -los hrönir derivados de otro hrön, los hrönir derivados del hrön de un hrön- exageran las aberraciones del inicial; los de quinto son casi uniformes; los de noveno se confunden con los de segundo; en los de undécimo hay una pureza de líneas que los originales no tienen. El proceso es periódico: el hrön de duodécimo grado ya empieza a decaer. Más extraño y más puro que todo hrön es a veces el ur: la cosa producida por sugestión, el objeto educido por la esperanza. ${ }^{38}$

Ahora bien, es obvio que Borges usa su conocimiento de las kenningar como elemento importante en este cuento. No lo usa directamente ni mucho menos, sino que se basa en el sistema, lo distorsiona y juega con él, ¿Lo podríamos llamar una paro-

${ }^{36}$ Ibid., pág. 21.

${ }^{37}$ Ibid., pág. 28. Hrön es masculino según Borges pero según el sistema islandés una palabra con el plural en -ir y una ene dentro de la palabra tendría que ser femenina. Además, el uso de la vocal ö refuerza la identidad islandesa,

38 J. L. Borges, Ficciones, pp. 28-29. La terminación más común de palabras masculinas en nominativo es ' $-\mathrm{ur}^{\mathrm{r}}$ ' en islandés. 
dia, lo cual reflejaría tanto su atracción como su postura crítica hacia ellas?

Antiguas literaturas germánicas (1951) y

Literaturas germánicas medievales (1965)

La afinidad del título de ambas obras indica la semejanza temática. En efecto, en lo que concierne a la literatura islandesa medieval, no hay ninguna diferencia entre los dos libros, solamente hay correcciones estilísticas mínimas. ${ }^{34}$ Antiguas literaturas germánicas fue editado en México en 1951; en él aparece el nombre de Delia Ingenieros como colaboradora, pero no se especifica en qué consistía su colaboración. ${ }^{40} \mathrm{El}$ otro libro, Literaturas germánicas medievales, fue editado en 1966. Curiosamente aparece otro nombre femenino como colaboradora, el de María Esther Vázquez. ${ }^{41}$ Dada esta semejanza entre los libros, es sorprendente lo que Rodolfo E. Modern dice en una reseña sobre Literaturas germánicas medievales:

${ }^{39}$ A continuación me refiero sólo a Antiguas literaturas germánicas al tratar el contenido de ambos libros.

${ }^{40}$ Lamentablemente he sido incapaz de encontrar información acerca de Delia Ingenieros a pesar de una bứsqueda vertiginosa. Cronológicamente podría ser la hija del filósofo argentino José Ingenieros, pero en el libro de Sergio Bagú, Vida ejemplar de José Ingenieros (Buenos Aires, 1953), no se mencionan los nombres de sus hijos: "La ciudad suiza vio también la culminación de su noviazgo iniciado en la patria lejana. En 1914, casó con Eva Rutenberg. El hogar que los dos argentinos formaron en el continente viejo vino después a robustecerse y hacerse fecundo en Buenos Aires, con la presencia de cuatro hijos y con esa intimidad y comprensión que crea la lucha diaria compartida", pág. 126. Esto es todo lo que se dice de la vida familiar del filósofo argentino, así que ésta no será más que una especulación mía que requiere más investigación.

${ }^{41}$ María Esther Vázquez trabajó con Borges desde 1959. Colaboró con él en dos libros: Introducción a la literatura inglesa (1965) y el libro aquí discutido. Ella misma ha publicado dos libros de cuentos: Los nombres de la muerte (1964) y Para un jardín cerrado (1970). De poesía, publicó Noviembre y el ángel (1968). De ensayos ha publicado Everness (1965), breve estudio de un poema de Borges, Soldi por Soldi (1970) y finalmente Borges: imágenes, memorias, diálogos (1977). 
Porque esta historia amplía y perfecciona, en buena medida gracias a su transcripción castellana de numerosos textos originales, una anterior del mismo Borges y Delia Ingenieros, publicada hace varios años por intermedio de una editorial mejicana. ${ }^{42}$

En mi opinión, no es visible este perfeccionamiento. Sin menospreciar la colaboración de las coautoras, es tentador fijarse con detenimiento en la fecha en que Borges empieza a hacer las obras en colaboración con autores diferentes a Bioy Casares. Esto ocurre en los años cincuenta, cerca de la fecha en que Borges quedó ciego.

Como he insistido en la similitud entre los dos libros, es de suponer que la,bibliografía reflejaría lo mismo. Al contrario, no parece pertenecer al mismo libro. Hay una diferencia turbadora y reveladora entre las bibliografías de los dos libros ya que refleja cierta evolución y un cambio de énfasis por parte de Borges. Ambas tienen valoraciones personales del autor y están en prosa continua, por decirlo así. El hecho de hacer la bibliografía en texto revela el carácter popular del libro, dirigido a curiosos. No hay rigidez académica. En la edición de 1951, Borges menciona 25 libros y además muchos títulos de las sagas en traducciones al inglés y al alemán. Quince años más tarde la bibliografía del en apariencia casi el mismo libro ha disminuido a 17 libros pero solamente siete de estos libros aparecen en la bibliografía de 1951. Es decir, al trabajar la bibliografía de 1966, Borges quitó 18 de los libros que usó en 1951 y añadió 10 libros nuevos. También dividió la bibliografía de 1966 en dos partes; "Pequeña bibliografía" y "Traducciones". Es una bibliografía mucho menos interesante que la de 1951 ya que el énfasis está en la lengua y no en la cultura. Añade libros como: An introduction to Old Norse, Teach yourself Icelandic, A concise dictionary of Old Icelandic, A concise Anglo-Saxon Dictionary, lo cual muestra que Borges había llegado más allá,

${ }^{42}$ Rodolfo E. Modern, "Vikingos, melancólicos y nibelungos", Testigo 4 (1966), pp. 118-19. 
ya había asimilado la cultura y no veía la necesidad de mencionar libros como English Literature from the beginning to the Norman Conquest, de S. A. Brook; The Icelandic Sagas, de William Craigie, e Island, Kultur zur Wikingerzeit, de Félix Niedner.

\section{Oralidad y crítica}

Hay que tener en cuenta que Borges no leía el islandés en los años treinta y todos los libros que usa son, por lo tanto, traducciones al inglés o al alemán. El espíritu predominante es el de hacer el trabajo de pionero e introducir una literatura desconocida para el mundo hispánico de una manera no puramente académica sino más bien dominada por el interés y curiosidad personal del autor. En uno de los libros, el autor lamenta la falta de conocimiento de la cultura escandinava:

Para la historia universal, las guerras y los libros escandinavos son como si no hubieran sido; todo queda incomunicado y $\sin$ rastro, como si acontecieran en un sueño o en estas bolas de cristal que miran los videntes. En el siglo XII, los islandeses descubren la novela, el arte de Cervantes y de Flaubert, y ese descubrimiento es tan secreto y tan estéril, para el resto del mundo, como su descubrimiento de América. ${ }^{43}$

Ahora, casi medio siglo más tarde, nadie ha superado este libro para el mundo hispanoparlante, e Islandia, con su literatura, sigue siendo una tierra lejana, o como dijo el propio Borges:

De las regiones de la hermosa tierra Que mi carne y su sombra han fatigado Eres la más remota y la más íntima, Última Thule, Islandia de las naves. ${ }^{44}$

${ }^{43}$ J. L. Borges, Antiguas literaturas germánicas, p. 87.

44 J. L. Borges, Obra poética, p. 403. 
Es menester evaluar los criterios de Borges acerca de esta 1iteratura y estimar su valor informativo. Aunque haya pasado mucho tiempo desde que Borges escribió Antiguas literaturas germánicas y Literaturas germánicas medievales, y mucho haya cambiado en las teorías de los estudios escandinavos, se puede ver el valor informativo teniendo en cuenta los criterios vigentes en aquel entonces. Su libro no es una investigación con las fuentes originales sino que está restringida a lo que se ha escrito en inglés o alemán acerca del asunto. No hay referencias a investigaciones escandinavas. Este hecho provocó en 1969 a un noruego, Mattias Tveitane, quien hizo una reseña muy crítica de la traducción noruega:

Som en orientering for et spansk publikum om en fremmed og fjern litteratur har den muligens sin verdi (boka har iallfall oppnådd å utkomme $\mathrm{i}$ et 2. oplag, 1965)- derimod tåler den knapt å presenteres på norsk. ${ }^{45}$ [Para un público español, puede ser útil como una orientación sobre una literatura poco conocida y lejana (el libro por lo menos ha logrado la segunda edición en 1965), sin embargo, apenas soporta ser presentado en noruego.]

Lo cito por ser el único testimonio de la reacción escandinava al libro. Es, sin embargo, una lástima que Tveitane no distinga claramente entre la traducción al noruego y el valor informativo del libro. Parece ponerlo todo en la misma cuenta. Le irritan mucho las incorrecciones ortográficas del texto. ¿Cómo va a exigir de un hispanoparlante que conozca y sepa usar letras como $\mathrm{P}, \partial, \mathfrak{x}$ y ö? También está escandalizado por la traducción al noruego que le parece ínfima y me convenció que sí lo es.

Lo que más se ha discutido en Islandia a lo largo de este siglo es si el origen de las antiguas literaturas escandinavas es oral o escrito, y aunque Borges no menciona la polémica, toma 58.

45 Mattias Tveitane, "Kommentar og kritikk", Edda 69 (1969), pp. $356-$ 
postura respecto de ella. Dice que el origen es oral y que no se conoce los autores:

Este arte empezó siendo oral; oír cuentos era uno de los pasatiempos de las largas veladas de Islandia. Se creó así, en el siglo $\mathrm{X}$, una epopeya en prosa: la saga [...] Una o dos generaciones de recitadores orales fijaron la forma de cada saga; éstas se escribieron después, con amplificaciones. No se ha guardado el nombre de los autores, porque no hubo autores; en el comercio oral, las repeticiones fueron puliéndolas, como ocurre con las anécdotas. ${ }^{46}$

Es interesante ver que Borges toma la postura de la oralidad porque, siendo escritor, le podría desafiar la demasiada importancia de lo oral. Me refiero al hecho de que un escritor que compone su obra corrigiéndola minuciosamente tendría problemas con aceptar una literatura de alta calidad como oral. Sin embargo, su postura está de acuerdo con su propia manera de escribir:

Ég segi vinum mínum og kunningjum smásögurnar mánuðum, jafnvel árum saman, áđur en parr eru skrifađar. Pannig fæe ég mörg góð ráđ, áður en pær komast á pappír. Pær verđa slípaðar og fullburða og ekki fæddar fyrir tímann. Pannig hafa einnig ýmis verk fornaldar verið unnin. ${ }^{47}$ [Meses, incluso años, antes de escribir los cuentos, las narro a mis amigos. Así recibo muchos buenos consejos antes de escribirlas. Se pulen y maduran y no nacen antes del tiempo. De este modo, varias obras de los tiempos pasados han sido trabajadas.]

El criterio más moderno y convincente en la crítica escandinava hoy en día dice que el origen es en parte oral. Se mantiene que la Edda poética y las sagas antiguas, además de las sagas islandesas, están basadas en mayor o menor grado en poemas y narraciones orales. Estas obras son anónimas. La cultura

46 J. L. Borges, Antiguas literaturas germánicas, p. 70 y 75 .

${ }^{47}$ Johannesen, op. cit., p. 226. 
escrita ha recibido esta oralidad, la ha trabajado y transformado de varias maneras. La mayoría de los académicos modernos está de acuerdo en ello, pero en la discusión se ha mezclado la tradición oral y los hechos históricos, por una parte, y por otra parte el origen escrito y la creación ficticia. No se debe mezclar esto, ya que leyendas o sagas orales pueden ser ficticias (como aventuras), al mismo tiempo que también pueden relatar algo que ocurrió. Es imposible definir la frontera entre la tradición oral y la escritura porque fluctúa. Helga Kress, profesora de literatura comparada en la Universidad de Islandia, dice que la tradición oral es polifónica mientras que la cultura escrita tiene solamente una voz. En la literatura islandesa medieval hay una tensión entre estas dos culturas. ${ }^{48}$

Tveitane no está de acuerdo con Borges y refleja la escuela que Kress llama "masculina", que no soporta lo popular ni la oralidad, que es tan femenina. Habla de la necesidad masculina de poner nombres de autores a las obras. Tveitane procede con su crítica a Borges:

Skandinavisk faglitteratur har han ikke brukt, og han behersker neppe origianltekstene godt nok. I hans framstilling opereres det enda med muntlig fortalte sägaer, skapt "i det 10. århundre" uten at nyere synsmåter er nevnt. ${ }^{49}$ [No ha usado crítica escandinava y apenas domina los textos originales bien. En su presentación está aún hablando de las sagas como de origen oral, creadas "en el siglo X" sin mencionar perspectivas más modernas.]

No se puede olvidar que Tveitane escribía en 1969, por lo cual no sorprende su actitud acerca del origen oral. La que sí es sorprendente es la opinión de Enrique Bernárdez quien afirma en 1992:

${ }^{48}$ Helga Kress, Máttugar Meyjar. Íslensk fornbókmenntasaga, Reykjavík, 1993, pp. 12-18, 79 y 175; también Carol J. Clover, "Icelandic Family Sagas (Íslendingasögur)", Clover y John Lindow, editores, Old Norse-Icelandic Literature. A Critical Guide, Islandica XLV, Cornell University Press, 1985, pp. 272-93.

4y Tveitane, op. cit, p. 356. 
[L]as sagas no se crearon en forma oral, sino que surgieron directamente sobre el pergamino, aunque ciertamente hubo narraciones orales anteriores, pero breves y seguramente no muy parecidas a las sagas que conservamos. Tampoco surgen en el siglo X, ni carecen de autores: se han propuesto con bastante certeza algunos para varias de las sagas más importantes. Borges no tenía por qué saber esto, pues la bibliografía que maneja es anticuada, ${ }^{50}$

Hay que decir que el debate entre los que postulan el origen oral y los que postulan el origen escrito sigue estando vivo y es difícil juzgar cuál es el de las sagas en conjunto. Por otro lado, no es tan anticuada la bibliografía de Borges en lo que se refiere a la oralidad, como dice Bernárdez, pero a continuación vamos a ver cómo maneja ciertos puntos específicos.

\section{El valor informativo}

Se sabe que, como Borges no ha investigado las fuentes originales, depende de traducciones y de lo que otros han sostenido. Ahora vamos a ver la exactitud de la información que nos da. Empezamos por ver cómo Borges presenta al historiador Ari porgilsson el Sabio: "Ari escribió el Konungabók o Libro de los Reyes". ${ }^{51}$ No existe nada que se llame Konungabók pero en la primera mitad de este siglo había unos cuantos académicos que mantenían que sí había existido. Se sabe que Ari escribió algo sobre los reyes noruegos, pero Jakob Benediktsson cree probable que se trate de un capítulo de la primera versión del Libro de los islandeses que no se conserva. ${ }^{52}$

El siguiente párrafo empieza así: "Su trabajo más famoso, el Landnámabók o Libro del Establecimiento, consta de cinco

so Bernárdez, op. cit., p. 364.

s: J. L. Borges, Antiguas literaturas germánicas, p. 96.

52 Íslendingabók. Landnámabôk I, ed. de Jakob Benediktsson, Reykjavík, 1968, pp. X-XIII. 
partes". A principios de este siglo se creía que Ari había escrito una versión de Landnámabók pero no hay ninguna evidencia de esto. No es improbable que tuviera algo que ver con alguna de sus partes, según la exactitud topográfica de la obra, se considera que fue escrita por más de una persona, pero se sabe poquísimo de los supuestos autores del libro y nada con certeza. Este asunto era ya muy discutido a principios de este siglo en Islandia y en Escandinavia, por lo que Borges no acudió a la información primaria. probablemente se contentó con lo que decían sus pocas fuentes secundarias y las tomó por verdaderas.

Borges continúa con Ari el Sabio: "Una tercera obra, el Íslendingabók o Libro de los Islandeses, compuesto hacia 1127, se ha perdido; queda un resumen en latín titulado Libellus Islandorum". Aquí hay un malentendido, bastante grave, ya que el Íslendingabók sî existe en islandés (unas treinta páginas en una edición impresa) pero no existe ningún ejemplar en latín. Lo que ha confundido a Borges es que la versión islandesa conservada del Libro de los islandeses es la segunda versión por parte de Ari, quien escribió la primera versión algunos años antes. Ésta no se ha conservado.

A pesar de estos defectos, el autor da una perspectiva de conjunto al lector que no conoce esta cultura. El aspecto mejor logrado del libro es el énfasis que Borges pone en relatar y parafrasear de una manera personal, divertida y subjetiva, las obras y escenas que más le han interesado. Con ello, permite al lector participar en su experiencia de encontrarse con las obras, disfrutando lo que más le ha impactado.

Claro que Borges no podía competir al nivel informativo con los estudiosos que hacían obras similares, pero en cuanto a la valoración literaria, da comentarios que sí valen mucho. Invita al lector a gozar de lo que ha leído o lo que le ha gustado en especial. Völsungasaga fue lo primero que leyó de esta literatura y por ello es tratada con esmero. Lo mismo pasa con - Egils saga, obra que Borges leyó, en la cual destaca la figura del héroe Egill; su identificación con él es obvia, ya que éste 
fue un autor de versos escáldicos que quedó ciego en su vejez. Al visitar Islandia le conmovió pasar por la finca donde Egill vivió los últimos años de su vida; dijo Borges, según relata Johannesen:

Ég á gott. Ég sé móta fyrir fjöllunum. Pað kemur sér vel fyrir mig að̃ vera blindur. Ég sé ekki bæina. Ég sé ekki sveitina. En ég sé fjöllin eins og Egill sá pau, pegar hann var orðinn blindur. Pannig stend ég í sporum Egils en ekki pið. bað eru forréttindi að vera blindur á bessum stað..$^{53}$ [Tengo suerte. Diviso las montañas. Es conveniente para mí ser ciego. No veo las fincas. No veo el distrito. Pero veo las montañas como las vio Egill, cuando se había quedado ciego. Así estoy en las huellas de Egill pero ustedes no. Es un privilegio ser ciego en este lugar.]

Sin menospreciar el valor informativo de Las antiguas literaturas germánicas y Literaturas germánicas medievales, libros que seguramente habrán despertado el interés de muchos hispanoparlantes por esta literatura y quizás fomentado el interés en la traducción de esta literatura en los últimos años, ${ }^{54}$ son más interesantes los comentarios del autor a lo largo del texto. Por una parte porque revelan su gusto $y$, por otra parte, porque nos indican qué és lo que tiene en común su propia obra con las sagas. Le atrae lo que se parece a su estilo. Estos comentarios son claves ya que a menudo parece que no está hablando de las sagas sino de su propia obra.

\section{Similitudes de estilo}

Lo que Borges escribió sobre la literatura islandesa medieval es interesante porque lo escribió él y no otra persona. En estos juicios tiene más trascendencia lo que dice sobre él mismo que lo que dice acerca de esa cultura, pues ya se ha mostrado que

53 Johannesen, op. cit., p. 225.

54 Gracias a Enrique Bernández el público hispanohablante tiene acceso a una variedad de literatura islandesa. 
el valor informativo del libro no es lo mejor. Es un tesoro verdadero porque sin estos libros es difícil trazar un subtexto islandés en la obra del autor.

En una entrevista con Matthías Johannessen en Islandia en 1971 se le preguntó qué había aprendido de la literatura antigua islandesa y contestó: "Sparsemi [...] Allir, sem skrifa á spænsku, hafa tilhneigingu til að teygja úr stílnum. Cervantes er sagður hafa verið raunsæishöfundur. En sögupersónur hans tala aldrei saman. Pær halda alltaf ræðu".55 [Economía. Todos los que escriben en español tienen la tendencia de extender su estilo. Dicen que Cervantes era un escritor realista. Pero sus personajes nunca dialogan. Siempre dan un discurso.] En efecto, el estilo y el tono de las sagas islandesas es lo que más ha influido en Borges.

En el libro Epic and Romance, escrito por W. P. Ker en 1896, se define el estilo de las sagas islandesas. Ker habla del tono narrativo que generalmente se parece al de una historia verdadera. Luego enfatiza la economía textual, es decir, la brevedad con que todos los incidentes son contados y la ausencia de comentarios explicativos. La definición de estilo que ofrece Ker es casi paralela a la que se da a la obra de Borges. ${ }^{56}$ Desde luego que este libro le impresionó al escritor ya que lo cita y lo menciona en la entrevista con Matthías Johannesen como un libro magnífico, y lo mismo hace en los libros que aquí se discuten. Es decir, se identifica fuertemente con Ker, puesto que debe haber sido para él como ver su propio estilo retratado. Lo interesante es que no sabemos si Borges era consciente de la semejanza que existe en cuanto a estilo o no. Dice acerca de las sagas:

El estilo es breve, claro, conversacional; suele incluir, como adorno, aliteraciones. Abundan las genealogías, los litigios, las

ss Johannesen, op, cit., pp. 221-22.

56 W. P. Ker, Epic and Romance, Londres, 1957, pp. 212-15. Fue Sigrún A. Eiríksdóttir que apuntó la similitud entre la definición dada por Ker y las sagas islandesas. 
peleas. EI orden es estrictamente cronológico; no hay análisis de los caracteres; los personajes se muestran en los actos y en las palabras. Este procedimiento da a las sagas un carácter dramático y prefigura la técnica del cinematógrafo. El autor no comenta lo que refiere. En las sagas, como en la realidad, hay hechos que al principio son oscuros y que luego se explican y hechos que parecen insignificantes y luego cobran importancia. ${ }^{57}$

No podemos saber si Borges era consciente de que era como si se estuviera mirando a sí mismo en el espejo, pero la similitud es obvia. Su economía textual es bien conocida así como su resistencia a entrometerse en sus personajes. Los tenemos que conocer por sus hechos y dichos. Borges, como las sagas, exige capacidad interpretativa por parte de su lector y no abunda en detalles. No obstante, éstos cobran importancia. Si analizamos la última frase de la cita: "En las sagas, como en la realidad, hay hechos que parecen insignificantes y luego cobran importancia", vemos que lo mismo se aplica a los cuentos de Borges. Sigrún Á. Eiríksdóttir, profesora de español en la Universidad de Islandia, menciona la misma característica, "deferred relevance", en varios cuentos del autor. Dice:

"Emma Zunz", "El inmortal", "El muerto", "El Aleph", and "El hombre de la esquina rosada" are some of the examples of Borges' marked tendency towards the gradual unravelling of plot, albeit in relatively few words, by means of assuming earlier and apparently insignificant detail into crucial points of the (tragic) action. ${ }^{58}$

Lo que a Borges le impresiona, lo usa en su ficción. Borges tiene en común con las sagas el hecho de que el dogma de la religión está ausente. Tampoco existe la tradicional dicotomía entre los buenos y los malos. La representación del hombre se realiza en un nivel superior, donde se refleja la complejidad de

57 J. L. Borges, Antiguas literaturas germánicas, p. 70.

${ }^{58}$ Sigrún Á. Eiriksdóttir, op. cit., pp. 384-85. 
la existencia humana. Es alucinante cómo las sagas han sido capaces de tratar el mundo pagano ya en la era del cristianismo, sin juzgar la religión antigua. Forma parte de la imparcialidad que vemos tan claramente en Borges. No sorprende, por lo tanto, como Borges ve Njála:

Se sospecha que el cristianismo, que dio su espíritu a la saga más fresca, la Njála, paradójicamente apresuró esa degeneración. La saga, como toda obra novelística, se alimenta de la riqueza y complejidad de los caracteres; la nueva fe acabó por vedarle esa contemplación desinteresada y le impuso un mundo dualista de virtuosos y de malvados, con penas para unos y con recompensas para otros. La saga decayó; se pobló de aventuras vertiginosas que, sin embargo, eran insípidas, porque no acontecían a gente real, sino a dechados de virtud o a monstruos de maldad. $^{59}$

A pesar del tratamiento general de las sagas, a Borges le fascinan escenas particulares que usa directamente en su obra. Una de ellas es de Heimskringla, la cual cita así en Otras inquisiciones:

Tostig, hermano del rey sajón de Inglaterra, Harold Hijo de Godwin, codiciaba el poder y se alió con Harald Hardrada. Con un ejército noruego desembarcaron en la costa oriental y rindieron el castillo de Jorvik (York). Al sur de Jorvik los enfrentó el ejército sajón. [...] Veinte jinetes se allegaron a las filas del invasor; los hombres, y también los caballos, estaban revestidos de hierro. Uno de los jinetes gritó:

- ¿Está aquí el conde Tostig?

- No niego estar aquí, dijo el conde.

-Si verdaderamente eres Tostig - dijo el jinete- vengo a decirte que tu hermano te ofrece su perdón y una tercera parte del reino.

-Si acepto —dijo Tostig - ¿qué dará al rey Harold Hardrada? -No se ha olvidado de él - contestó el jinete. Le dará seis pies de tierra inglesa y, ya que es tan alto, uno más.

${ }^{59} \mathrm{~J}$. L. Borges, Antiguas literaturas germánicas, p. 86. 
—Entonces - dijo Tostig — dile a tu rey que pelearemos hasta morir.

Los jinetes se fueron. Harold Hardrada preguntó pensativo:

- ¿Quién era ese caballero que habló tan bien?

- Harold Hijo de Godwin. ${ }^{60}$

Tostig sabía todo el tiempo que estaba hablando con su hermano. Recordemos el encuentro entre Rosendo y Francisco Rojas en "El hombre de la esquina rosada", donde éste se acerca a Rosendo y pregunta por él, sabiendo perfectamente con quién está hablando. ${ }^{61}$ Es un juego psicológico que crea suspenso y se basa en las mismas circunstancias que la escena de Heimskringla. El subtexto es obvio pero aquí sería quizás más adecuado llamarlo reescritura.

A Borges le atraían especialmente escenas donde el héroe recibía su muerte con mucha valentía, muy a menudo mezclando humor e ironía. Una de ellas es de Grettis saga cuando Atli fue asesinado. Borges no usa esta escena como materia para otro relato, sino que la reproduce enteramente en "Destino escandinavo", donde lo pone como un ejemplo excelente de esta literatura. ${ }^{62}$ No he podido ver esta escena recreada en su obra como ocurrió en el pasaje anterior de Heimskringla pero lo importante es ver que Borges usa la literatura islandesa tanto directa como indirectamente.

\section{"La intrusa"}

He escogido un cuento que Borges dijo que escribió imitando el modelo de las sagas. Es "La intrusa", escrito de 1966, del

${ }^{60}$ Ibid,, p. 116. Borges cita la misma escena de Heimskringla en Otras inquisiciones, "El pudor de la historia", Buenos Aires, 1986, pp. 214-16. Fue mi profesor, James Irby, quien me llamó la atención sobre este punto.

61 J. L. Borges, Historia universal de la infamia,"El hombre de la esquina rosada", Alianza, Madrid, 1991, pp. 93-107.

${ }^{62}$ J. L. Borges, "Destino escandinavo", Sur 219-220 (enero-febrero de 1953), p. 12. 
que él mismo declaró que era su mejor cuento en la entrevista con Matthías:

Ég held, að bezta sagan sem ég hef skrifað - kannski eina sagan, sem ég hef skrifað— sé frásögnin "Sú óboðna", með skírskotun í 2. Konungabók. Ég skrifaði pessa sögu í stíl og anda Íslendingasagna. ${ }^{63}$ [Creo que el mejor cuento que he escrito —quizás el único cuento que he escrito- es la narración "La intrusa", con referencia a 2. Reyes. Lo escribí según el estilo y espíritu de las sagas islandesas.]

Un islandés que lee este cuento por primera vez, no dice: ¡ahí está lo antiguo islandés! No, es al contrario. Lo islandés no yace en la superficie, el ambiente es auténtico al de la Argentina. Hay que detectar el subtexto y éste se basa en lo que Borges valoró y admiró en las sagas, es decir, la técnica narrativa y el estilo.

Primero es la alusión a la oralidad. El autor rescata la tradición oral y la pone en letra. El cuento empieza: "Dicen (lo cual es improbable) que la historia fue referida por Eduardo". Luego sigue: "Lo cierto es que alguien lo oyó de alguien". ${ }^{64} \mathrm{La}$ tradición oral fascina a Borges, como hemos visto acerca del origen de las sagas. Habla de la segunda versión oral del cuento

${ }^{63}$ Johannesen, op. cit., p. 242. Antes consideraba el "Sur" como su mejor cuento pero mantiene lo mismo acerca de "La intrusa" en una entrevista con Richard Burgin. Véase Gary D. Keller y Karen S. Van Hooft, "Jorge Luis Borges: 'La intrusa'", en Lisa E. Davis e Isabel C. Tarán, eds., The Analysis of Hispanic Texts: Current Trends In Methodology, Nueva York, 1976, p. 318 . En cuanto a la referencia al texto bíblico que encabeza el cuento, $2 \mathrm{Re}-$ yes I, 26, el lector se encuentra con que no existe tal segundo libro de Reyes I, 26. No obstante en la traducción al inglés hecha por Norman Thomas di Giovanni en colaboración con Borges, el contenido es citado brevemente ("passing the love of women"). Esta cita no es de 2 Reyes sino del capítulo anterior, 2 Samuel 1, 26, donde dice: "Por ti estoy apenado, Jonatán, hermano mío, por ti, a quien tanto yo quería. Tu amistad era para mí más maravillosa que el amor de las mujeres". (La Biblia, Madrid, 1979). Keller y Van Hoft interpretan este amor fraterno como homosexual lo cual no me convence, ya que Borges dice que escribe el cuento en el mismo espíritu de las sagas donde la amistad y la lealtad tienen importancia suprema.

${ }^{64}$ J. L. Borges, Narraciones, Cátedra, Madrid, 1986, p. 189. 
en la cual se basa el que la escribe: "La escribo ahora porque en ella se cifra, si no me engaño, un breve y trágico cristal de la índole de los orilleros antiguos. Lo haré con probidad, pero ya preveo que cederé a la tentación literaria de acentuar y agregar algún pormenor". ${ }^{65}$ Recoge un pasado, un pasado oral, y lo reentrega al pueblo agregando lo suyo de la misma manera como se hace en las sagas. Hay en las sagas una unión entre la tradición oral y la tradición escrita, y se puede ver la tensión interna que existe entre las dos tradiciones. Recordemos lo que dijo acerca de las sagas: "Una o dos generaciones de recitadores orales fijaron la forma de cada saga; ésas se escribieron después, con amplificaciones". ${ }^{66}$ Borges se ha puesto en las huellas del escritor de las sagas y pone lo oral en el 'pergamino'.

Los hermanos, Cristián y Nelson, no solamente están unidos por la sangre sino que también hay entre ellos una amistad sincera. "Hombre a hombre pelearon una vez a la policía". ${ }^{67}$ Allí surge el sistema 'religioso' de la literatura islandesa llamado fóstbraðralag o 'hermandad de sangre'. Era un juramento entre hombres que consistía en defenderse uno al otro hasta la muerte, y que hacía que, ante enemigos, fueran como un solo hombre. Tenían que vengar el uno por el otro o como dice en "La intrusa", "Malquistarse con uno era contar con dos enemigos". ${ }^{68}$ Valentía y lealtad eran los valores principales. La lealtad era mucho más importante que el amor, lo cual aparece claramente en el cuento: los hermanos prefieren la amistad entre sí al amor. Lo mismo se puede leer tanto en Laxdcklasaga como Fóstbrceðrasaga. En Laxdcelasaga, Kjartan no quiere ir a Noruega con Guðrún, su amor, pero se va con su fóstbróðir Bolli. $\mathrm{Su}$ amistad es casi sexual, pues cada uno no resiste la ausencia del otro. En Fóstbraðrasaga, Pormóður tiene sus encuentros

${ }^{65}$ Ibid., pp. 189-90.

${ }^{66}$ J. L. Borges, Antiguas literaturas germánicas, p. 70.

${ }^{67}$ J. L. Borges, Narraciones, p. 190.

${ }^{68}$ Ibid. 
amorosos cuando no está de héroe con su fóstbródir Porgeir a quien prefiere a sus amantes. La alianza entre los hombres supera sentimientos como el amor.

Los hermanos no hablan de sus sentimientos, pero sus hechos hablan por los dos. Cristián dice: "Yo me voy a una farra en lo de Farías. Ahí la tenés a la Juliana; si la querés, usála" ${ }^{69}$ Esta frase lo dice todo: está dispuesto a compartir su mujer porque le importa más la amistad de su hermano. No lo discuten más y la opinión de Juliana no viene a cuento porque es tratada, con una misoginia tremenda, como una 'cosa'.70

No hay palabra superflua en el texto. La economía textual es impresionante. El relato, que tanto nos cuenta, ni siquiera llena cinco páginas. Está de acuerdo con el estilo islandés. Veamos por ejemplo la descripción de Juliana. "Juliana era de tez morena y de ojos rasgados, bastaba que alguien la mirara para que se sonriera. En un barrio modesto, donde el trabajo y el descuido gastan a las mujeres, no era mal parecida". ${ }^{71}$ Allí tenemos la información esencial de la mujer en dos frases. Habría quienes se hubieran extendido más en la descripción de la mujer, personaje importante, pero aquí cada palabra pesa mucho. La descripción requiere sin duda el pensamiento del lector y su habilidad de interpretar una descripción que roza con lo irónico. Juliana es realmente ridícula, pero el ambiente en que está apacigua estos rasgos. Es genial la última frase donde mediante la lítote subraya la apariencia de Juliana: "no era mal parecida". El uso irónico de la lítote es muy común en las sagas. En islandés, este tropo se llama úrdráttur e incluye tanto lítote como meiosis. Es una de las características humorísticas más importantes de las sagas. Veamos este ejemplo de la Saga de Njáll: “Guð-

${ }^{69}$ Ibid., p. 191.

${ }^{70}$ Borges discute más que "foster-brotherhood" en este cuento. Exagera las relaciones entre los sexos lo cual es una buena manera de llamar la atención sobre la seriedad del machismo. Nadie puede leer el cuento sin advertir lo atroz que es el tratamiento que recibe la pobre mujer. Esto podría servir para que alguien tome conciencia del asunto.

71 J. L. Borges, Narraciones, p. 191. 
brandur spurð̃i: 'Hví er blóðug öx pín?' 'Eg gerði að bakverk Ásvarðar verkstjóra píns' segir Hrappur”. ${ }^{72}$ [Guðbrandur preguntó: “¿Por qué está manchada de sangre tu hacha?”, "Alivié el dolor de la espalda de Ásvörður, tu ayudante" contestó Hrappur.] De esto trata precisamente el cuento "La intrusa". Es una meiosis por excelencia, en la que Borges nos cuenta cómo los hermanos abusan de la pobre Juliana, la maltratan como una cosa. Cuando Cristián la mata, la echan en el campo para ser devorada por los buitres. Es realmente algo repugnante, pero Borges lo cuenta con inocencia, como si no fuera nada y ahí está el truco. El hecho de restar importancia a este hecho tan atroz, aumenta y multiplica el impacto que tiene. Así mantiene el suspenso.

Este cuento borgiano es especial en un sentido. El tema es principalmente moral y no intelectual o filosófico, como en la mayoría de sus cuentos. Concuerda con las sagas islandesas donde el tema principal es ético, envuelto en una problemática existencial. El autor ha logrado lo que se propuso:

Pegar ég skrifaði hana, reyndi ég að ganga eins hreint til verks og höfundar íslendingasagna. Ég hafði pær að fyrirmynd. Vinátta er mjög mikilvæg með pjóð minni. Mér fannst ekki viðeigandi að láta bræđurna berast á banaspjótum út af kvenmanninum. Fórnaði pví stúlkunni. Engin lausn önnur var á sögunni. ${ }^{73}$ [Cuando lo escribí intenté proceder como los autores de las sagas islandesas. Las tuve como ejemplo. La amistad es muy importante para mi gente. No me parecía adecuado hacer que los hermanos lucharan por la mujer y por eso la sacrifiqué. No había otra solución para el cuento.]

A pesar de que podría ser discutible el valor de la información que Borges da en Antiguas literaturas germánicas, es indiscutible la sensibilidad del escritor por dicha literatura. En este cuento ha mostrado su capacidad de elaborar el estilo y la

72 "Brennu-Njálssaga”, Íslendingasögur I., Reykjavík, 1987, p. 224.

${ }^{73}$ Johannesen, op. cit., p. 221. 
técnica de las sagas recreando el ambiente 'bárbaro' islandés, como lo llamaba él, en un barrio pobre de la Argentina de una manera excelente.

\section{Conclusiones}

La pasión que Borges sintió por la literatura escandinava fue algo que estuvo presente la mayor parte de su vida, al menos desde que publicó Las kenningar, en 1933, hasta su traducción de Gylfaginning, dos años antes de su muerte. En cuanto a su acercamiento, se limita estrictamente a la Edad Media y no hace ninguna conexión con la literatura islandesa contemporánea, como si Islandia existiera para él 'de un modo verbal' a nivel de literatura medieval. ${ }^{74} \mathrm{La}$ versión de las kenningar que presenta es original para el ojo islandés, ya que presenta las kenningar más universales, las que no tienen que ver con la mitología nórdica. Las ve como un juego de palabras y de inteligencia, y omite las kenningar complicadas. Después, vemos las kenningar reflejadas, implícita y explícitamente, en su obra. De manera explícita, lo podemos ver en poemas como "Fragmento"; de manera implícita aparece claramente en el cuento "Tlön, Uqbar, Orbis, Tertius". Por parte del autor hay una tensión entre atracción y repudio, puesto que simplifica este sistema de metáforas y lo representa de una manera accesible, excluyendo su temática más voluminosa, la mitología nórdica.

En cuanto al valor informativo de sus libros Antiguas literaturas germánicas y Literaturas germánicas medievales, libros casi idénticos y publicados con un intervalo de quince años, es una limitación que el autor no haya tenido acceso a la crítica escandinava, aparte de que en ellos se observan algunas fallas. Tampoco tiene mucho sentido valorar la información del libro más de cuarenta años después de su publicación. Desde enton-

${ }^{74}$ J. L. Borges, "Destino escandinavo", p. 12. 
ces ha corrido mucha tinta en el mundo académico, como vemos respecto al tema del origen oral, pero procuré poner sus ideas en el contexto de la época en que escribió. No obstante, su gran mérito es que establece un puente entre la cultura hispánica y la escandinava que no ha sido mejorado hasta ahora. Borges mantiene que el origen de las sagas es oral mientras en su época se solía decir que era escrito. Hoy en día sin embargo los académicos modernos están más o menos de acuerdo con Borges.

La descripción de Ker del estilo de las sagas podría ser una descripción del propio estilo de Borges. El cuento "La intrusa" fue escrito al estilo islandés; allí las características estilísticas de las sagas están entretejidas en una narración que tiene un ambiente argentino. Borges domina este estilo y la habría gustado conversar con Halldór Laxness sobre la recreación del mundo de las sagas en la literatura del siglo veinte. ${ }^{75}$ Es el momento de tratar de contestar la pregunta planteada al principio del trabajo: me propuse aclarar si se puede hablar de un subtexto islandés en la obra de Borges, o si se trata simplemente de que las sagas le gustaron tanto porque veía que tenía mucho en común con ellas. Bernárdez no vaciló a la hora de meditar sobre este punto. Al hablar del estilo de Borges dice:

Creo que se puede establecer una cierta similitud con el carácter de bastantes narraciones del mismo Borges. Seguramente no surgió por influencia de las sagas, pero sí considero probable que el gusto de Borges por éstas fuera, entre otras cosas, una consecuencia de sus propias preocupaciones literarias. ${ }^{76}$

Bernárdez rotundamente niega una influencia directa de las sagas en la obra de Borges. En mi opinión creo que a ambas preguntas que propuse al principio se puede contestar con un sí

${ }^{75}$ Halldór Laxness escribió la novela clásica Gerpla, una parodia de Fóstbr ąðrasaga usando el estilo y tono de las sagas.

${ }^{76}$ Bernárdez, op. cit., pp. 363-64. 
y un no. Veo difícil negar una influencia de las sagas en la obra de Borges y he demostrado un subtexto claro en su obra, pues el contacto constante con la literatura islandesa debe haber dejado huellas en su modo de escribir. Al mismo tiempo, es muy probable que sus preocupaciones literarias lo llevaran a profundizar en la literatura islandesa. Allí veía un estilo que estaba de acuerdo con su criterio literario. Por lo tanto, no creo que su estilo sea algo que haya descubierto en las sagas, sino que es el resultado de una cierta dialéctica, de acuerdo con la cual trabajaron juntos las preocupaciones literarias del autor y lo que encontró en las sagas. 